\title{
Diversity of Arbuscular Mycorrhizal Fungi of Different Plant Species Grown in Three Land Use Types in Wensho and Shebidino Districts of Sidama in Southern Ethiopia
}

\author{
Beyene Dobo ${ }^{1, *}$, Fassil Asefa ${ }^{2}$, Zebene Asfaw ${ }^{3}$ \\ ${ }^{1}$ Department of Natural Resources Management and Environmental Sciences, Haramaya University, Haramaya, Ethiopia \\ ${ }^{2}$ Department of Microbial, Cellular and Molecular Biology, Addis Ababa University, Addis Ababa, Ethiopia \\ ${ }^{3}$ Wondo Genet College of Forestry and Natural Resources, Hawassa University, Hawassa, Ethiopia \\ Email address: \\ beyeneashl@yahoo.co.uk (D. Beyene), asefafasi12013@gmail.com (A. Fassil),zebeneasfaw@yahoo.co.uk (A. Zebene) \\ ${ }^{*}$ Corresponding author
}

\section{To cite this article:}

Beyene Dobo, Fassil Asefa, Zebene Asfaw. Diversity of Arbuscular Mycorrhizal Fungi of Different Plant Species Grown in Three Land Use Types in Wensho and Shebidino Districts of Sidama in Southern Ethiopia. Advances in Bioscience and Bioengineering.

Vol. 4, No. 4, 2016, pp. 25-34. doi: 10.11648/j.abb.20160404.11

Received: June 13, 2016; Accepted: July 1, 2016; Published: July 21, 2016

\begin{abstract}
Diversity of arbuscular mycorrhizal fungi (AMF) of culturally protected forest, agroforestry practices, and monocropping lands has been investigated in Wensho and Shebedino districts of Sidama Zone in Southern Ethiopia. Rhizosphere soil and root samples of plant components from each land use type were analyzed for spore density, diversity and AM-root colonization. Except some non-mycorrhizal plants, all plants surveyed in the three land-use types showed AMF colonization ranging from 50 to $91 \%$. A total of 29 AMF morphospecies, belonging to nine genera (Acaulospora, Glomus, Claroideoglomus, Funneliformis, Pacispora, Septoglomus, Rhizophugus, Scutellospora and Gigaspora), were identified in the rhizospheres of selected plants in the three land uses. Spores of four genera Rhizophugus, Glomus, Funneliformis, and Acaulospora had higher spore production, accounting for $36.22 \%, 21.20 \%, 19.39 \%, 17.54 \%$ and $11.74 \%$ of the total number of spores respectively. One-way analysis of variance (ANOVA) showed that spore density and root colonization of different AM structures varied greatly among plant species both within and between different land-use types. Spore density was higher in culturally protected forest and AM colonization was higher in the agroforestry. The lowest number of spores and the lowest percentage of root colonization were recorded in cropland. When land use types were considered separately or together no significant correlation between spore densities and AM colonization was observed. The result of the study indicates that monocropping reduces spore density and AM colonization in comparison with the culturally protected forest and the agroforestry.
\end{abstract}

Keywords: Agroforestry, Arbuscular Mycorrhizal Fungi, Colonization, Crop Land, Spore Density, Rhizosphere, Agroecosystem

\section{Introduction}

Conversion of forests to agricultural lands is one of the leading causes of loss of biodiversity and land degradation [21]. In areas that are devoid of vegetation intense rainfalls on undulating landscapes during wet seasons accelerate soil erosion and land degradation. The clearing of vegetation cover from an agro-ecosystem also affect the diversity and population density of the underground life that include bacteria, algae, fungi, nematodes, and small invertebrates.
These organisms influence ecosystem processes in nature and determine plant diversity in natural communities.

One of the important microorganisms in the soil are arbuscular mycorrhizal fungi that form symbiotic association with roots of $>80 \%$ of the existing terrestrial plants [28]. This plant-fungal relationship is considered to be mutualistic, in which the fungus derives carbon from the host, and in return the plant gains several potential benefits from this association. AMF absorbs nitrogen $(\mathrm{N})$, phosphorus $(\mathrm{P})$, potassium $(\mathrm{K})$, calcium $(\mathrm{Ca})$, sulfur $(\mathrm{S})$, copper $(\mathrm{Cu})$, and zinc $(\mathrm{Zn})$ from the soil and translocate them to associated 
plants [23]. The AMF also improve soil structure [24], water relations of the plant [2], reduce root pathogenic infections and promote plant growth and adaptation to biotic and abiotic factors [3].

According to EFAP [10], during the last 100 years, approximately $40 \%$ forest coverage in several parts of Ethiopia is declined to just 3\%. Many of the vegetation cover have been changed to different agricultural systems and settlements to accommodate and feed the ever-increasing population. Although most of the land have been changed to mono cropping fields in low-input small holding agricultural system, some of the dry and wetlands are changed to mixed cropping and agroforestry systems. There are also few natural and protected forests and forest relics that maintain the natural vegetation. Three of these forests in Sidama of southern Ethiopia include a long-standing culturally protected semi-natural forests of Bokasso, TellamoTumano and Arrosa forests.

These forest areas are covered by vegetation, ranging from thick forest at their picks to sparsely vegetate lower slopes. Increasing population pressure, deforestation for agriculture and settlement, fuel, overgrazing, and cutting trees for pulp and construction have intensively disturbed almost all of these ecosystems in recent years. Over the past years part of these forests has undergone changes inland use, and lower slopes of the forest has been changed into agroforestry systems with trees intercropped with annuals and perennial crops and low input mono-cropping plots with mostly practiced trees, crops and different types of pulses.

It is established that changing traditional intact forests or vegetation cover into different production systems (agroforestry, cropping systems) lead to loss of plant diversity. This is due to the reduction of understory microbial diversity, mainly AMF which are associated with survival of individual plants and plant communities [30].

According to [30] the composition and dynamics of populations of AMF have a marked effect on the structure and diversity of the associated plant communities, both in natural and agricultural ecosystems. This maintenance of diversity of mycorrhizae in soil is important to sustain biodiversity and promote productivity of croplands, rangelands and forests [1].

Apart from that restoration of degraded ecosystem also require the diversity of $\mathrm{AMF}$ in relation to the specificity to plants that enhance their nutrition and soil stabilization. To this end, in order to maximize the rehabilitation and stabilization of the ecosystem the study on the effect of intensive land use changes in relation to biological diversity and density of AMF and other essential microorganisms is of paramount importance.

Sidama zone is one of the areas where land cover has been changed to different production systems to accommodate the increasing population and maintain food production. For many years from now, the relatively intact natural forest has been changed to different monocrop and agroforestry systems that may have also impacted on soil microbial communities.

The objectives of this study, therefore, is to assess the status of AMF colonization, spore density, and species composition of a culturally protected natural forest relics of Sidama Zone in relation to the adjacent change in land cover into agroforestry practice, and crop land ecosystems.

\section{Materials and Methods}

\subsection{Study Site}

The study was conducted in the three land use types in Abbo (Bokasso), TellamoTumano, and Arrosa areas of Sidama Zone in Southern Ethiopia. The study sites lie between $06^{\circ} 45^{\prime} 333^{\prime \prime} \mathrm{N}$ and $06^{\circ} 54^{\prime} 713^{\prime \prime} \mathrm{N}$ North latitude and $038^{\circ} 27^{\prime} 432^{\prime \prime} \mathrm{E}$ and $038^{\circ} 31^{\prime} 788^{\prime \prime} \mathrm{E}$ East longitudes and within altitudes ranging from 1740 to 2135 masl. The annual mean temperature was $15-20^{\circ} \mathrm{C}$ of which most of the mean annual precipitation of $1000-1800 \mathrm{~mm}$ falls during long rainy seasons from early May to late September. The three land-use types included: i) culturally protected forest composed of indigenous trees, bushes and shrubs, partly allowed for cattle grazing, ii) agroforestry system with a combination of trees, shrubs, and perennial crops and iii) land use with perennial crops such as coffee and Enset intercropped with annual crops (vegetables, cereals, pulses). All the three land-use types were located adjacently within $5 \mathrm{Km}$ distance from one another.

\subsection{Soil Sampling and Analysis}

Plant roots and rhizosphere soil samples were collected from the sampling sites in November and December, 2012. Sample plots within $10 \mathrm{~m} \times 10 \mathrm{~m}\left(100 \mathrm{~m}^{2}\right)$ quadrats were randomly selected to collect soil samples from the rhizospheres of representative plants. Triplicate soil samples from 0 to $15 \mathrm{~cm}$ depth were composited, air dried and collected in $1 \mathrm{~kg}$ sterilized plastic bags. A total of ninety three soil samples (3 (10 forest relics +13 agroforestry practices + 8 crop land) $\times 1$ soil depth) were collected. About $500 \mathrm{~g}$ of the soil samples were crushed, homogenized and passed through a $2 \mathrm{~mm}$ sieve before soil analysis. The second portions of the samples were used for spore count and taxonomic analysis. Soil analysis was undertaken at the SNNPR soil laboratory and Debrezeit Agricultural Research Center following standard procedures and methods. The fine root samples $(0.5 \mathrm{mg})$ were cut into $1 \mathrm{~cm}$ pieces, washed with tap water, preserved in $50 \%$ ethanol and stored at $4{ }^{\circ} \mathrm{C}$.

\subsection{Root Colonization}

AMF colonization was assessed according to [20]. Root samples were washed several times with tap water and cleared in $10 \%(\mathrm{w} / \mathrm{v}) \mathrm{KOH}$ by heating in a water bath at $90^{\circ} \mathrm{C}$ for $1-2 \mathrm{hrs}$ and cooled at room temperature. After cooling, the root samples were washed 3-5 times with tap water, acidified in $1 \% \mathrm{HCl}$ for $1 \mathrm{hr}$ and stained with $0.05 \%$ trypan blue and finally distained in acidic glycerol. The AM fungal structures were observed under a compound-light microscope (Olympus-bx 51) at 200 fold magnification. Fungal colonization was estimated using the magnified 
intersection method of [17] as total root length colonization $\mathrm{RLC}=100[(\mathrm{G}-\mathrm{N}) / \mathrm{G}]$, the percentage of root length colonized by arbuscules, arbuscular colonization $\mathrm{AC}=100(\mathrm{~A} / \mathrm{G})$ and the percentage of root length colonized by mycorrhizal vesicles, vesicular colonization $\mathrm{VC}=100(\mathrm{~V} / \mathrm{G}) . \mathrm{RLC}, \mathrm{N}, \mathrm{A}$, $\mathrm{V}$ and $\mathrm{G}$ are designated as RLC (total root length colonization), N (no fungal structure), A (arbuscules), V (vesicles) and $\mathrm{G}$ (total intersection) respectively. All were quantified by examining 100-150 intersections per sample.

\subsection{Spore Density}

Spore count was processed and determined according to [4]. Accordingly, $100 \mathrm{~g}$ of each soil sample was suspended into 2 liter container and mixed vigorously to free spores from the soil and roots. The supernatant was subsequently decanted through standard sieves $(480,106,50 \& 38 \mu \mathrm{m})$ after having been intermittently centrifuged at 2000rpm for 5 minutes. The last pellet $(38 \mu \mathrm{m})$ was suspended in $60 \%$ sucrose solution and thoroughly mixed and centrifuged at 2000rpm for 1 minute to collect the spores. The spores and sporocarps were then rinsed with tap water and transferred into plastic petri-dishes. They were counted under $4 \mathrm{x}$ stereomicroscope according to INVAM (2006) and spore densities were expressed as the number of spores and sporocarps per $100 \mathrm{~g}^{-1}$ of dry soil. Healthy looking spores were collected and mounted on slides with polyvinyl-lactic acid-glycerol (PVLG) or PVLG mixed with Melzer's reagent $(1: 1 / v)$ to identify them into the representative morphspecies based on the descriptions of the International Culture Collection of Vesicular/Arbuscular Mycorrhizal Fungi (http://invam.caf.wvu.edu; 2006), and following descriptions by [22] using a compound light microscope (Olympus-bx 51) at X200 magnification.

Ecological AMF diversity indices were used to determine differences in the structure of the AMF communities on different plant species in different land uses: The isolation frequency (IF) of occurrence was calculated as the percentage of samples in which a genus or species occurred among all samples and it reflects the distribution status.
Relative spore density (RD) was defined as the ratio between the spores' densities of a particular genus or species to the total AMF density in a given soil. The important value (IV) was used to evaluate the dominance of AMF species based on IF and $\mathrm{RD}$ and was calculated as $\mathrm{IV}=(\mathrm{IF}+\mathrm{RD}) / 2$. An IV $\geq 50 \%$ indicate that a genus or species is dominant; $10 \%$ $<\mathrm{IV}<50 \%$ applies to common genera or species; and IV $\leq 10 \%$ indicates that a genus or species is rare [7].

\subsection{Statistical Analysis}

Data on spore abundance and root colonization was $\log (\mathrm{x})$ and arcsine (the inverse sine of the square root of the proportion) transformed using PAST3 (ver. 1.0.0.0) and SPSS software package (version 20.0) respectively, prior to analysis to meet assumptions of ANOVA such as normality and homogeneity of variance. Significance of differences in AM fungal spore abundance and percentage of root colonization between the samples was tested using Fisher's least significant difference (LSD) at $\mathrm{p}<0.05$ after one-way analysis of variance (ANOVA) with the SPSS software package (version 20.0). Calculation of species richness (S), Shannon-Weaver diversity index, Simpson's Index of Diversity 1-D, isolation frequency (IF), and relative spore abundance (RA) were carried out according to [14].

\section{Results}

\subsection{Soil Physicochemical Properties}

The data showed that the soil samples were sandy clay loam in Bokasso area and sandy loam in Tellamo and Arrosa forest areas with a pH ranging from 6.18 to 6.28. Soil samples from the three land use types were different in many of the tested parameters. When considering the three land uses independently $\mathrm{pH}$, and bulk density (BD) were not significantly different from one another at $\mathrm{P}<0.05$ level (Table 1). The data also showed that cropping land use types were slightly lower in $\mathrm{pH}, \mathrm{SOC}, \mathrm{C}: \mathrm{N}$ ratio, available phosphorus and in two of the basic cations (Table 1).

Table 1. (Mean \pm SEM) Physical and chemical properties of the experimental soils in the three land use types.

\begin{tabular}{|c|c|c|c|c|c|c|c|c|c|c|}
\hline Af & $\mathrm{pH}\left(\mathrm{H}_{2} \mathrm{O}\right)$ & SOC $\%$ & TN\% & $\mathbf{C} / \mathbf{N}$ & $\begin{array}{l}\text { P Olson } \\
(\mathrm{mg} / \mathrm{kg})\end{array}$ & $\begin{array}{l}\text { Cacmol } \\
(+) / \mathbf{k g}\end{array}$ & $\begin{array}{l}\text { Mg cmol } \\
(+) / \mathrm{kg}\end{array}$ & $\begin{array}{l}\text { K cmol } \\
(+) / \mathbf{k g}\end{array}$ & $\begin{array}{l}\text { Na cmol } \\
(+) / \mathbf{k g}\end{array}$ & BD $\left(\mathrm{g} / \mathrm{cm}^{3}\right)$ \\
\hline $\mathrm{CPF}$ & $6.2 \pm 0.2 \mathrm{a}$ & $5.9 \pm 0.1 \mathrm{a}$ & $0.4 \pm 0.0 \mathrm{a}$ & $15.7 \pm 0.3 b$ & $22.6 \pm 0.5 \mathrm{a}$ & $3.6 \pm 0.1 \mathrm{~b}$ & $0.37 \pm 0.0 \mathrm{c}$ & $2.37 \pm 0.2 \mathrm{a}$ & $1.02 \pm 0.1 \mathrm{~b}$ & $0.94 \pm 0.0 \mathrm{a}$ \\
\hline $\mathrm{AF}$ & $6.28 \pm 0.0 \mathrm{a}$ & $3.47 \pm 0.1 \mathrm{~b}$ & $0.18 \pm 0.0 \mathrm{c}$ & $20.0 \pm 1.9 \mathrm{a}$ & $17.61 \pm 0.6 b$ & $2.78 \pm 0.3 \mathrm{c}$ & $0.47 \pm 0.0 \mathrm{~b}$ & $2.26 \pm 0.1 \mathrm{a}$ & $0.91 \pm 0.0 \mathrm{~b}$ & $0.98 \pm 0.0 \mathrm{a}$ \\
\hline $\mathrm{CL}$ & $6.18 \pm 0.1 \mathrm{a}$ & $3.04 \pm 0.1 \mathrm{~b}$ & $0.24 \pm 0.0 \mathrm{~b}$ & $12.67 \pm 0.7 \mathrm{c}$ & $15.13 \pm 0.3 c$ & $6.41 \pm 0.2 \mathrm{a}$ & $2.11 \pm 0.0 \mathrm{a}$ & $1.96 \pm 0.0 \mathrm{~b}$ & $0.35 \pm 0.0 \mathrm{a}$ & $0.97 \pm 0.0 \mathrm{a}$ \\
\hline
\end{tabular}

Key: $C P F$, culturally protected forest; AF, agroforestry; $C L$, cropland. Similar letters in columns for each land use type show not significant difference between land uses at $\mathrm{p}<0.05$.

\subsection{Root Colonization and Spore Density}

All plants formed AM symbiosis, with vesicles and arbuscules, except Brassica integrifolia that did not show extensive mycorrhization and with a small number of spores in the rhizosphere. The pattern of colonization of vesicles (VC) and arbuscules (AC) showed that vesicles cover the largest (average 26.66-33\%) area of the roots of the plants irrespective of the land use systems compared to AC (13.67-20.91\%)
(Table 2). AM-colonization of the same species from different land-use types showed variable patterns (Tables 2). Accordingly, percentage of vesicular colonization in Cordia africana, Millettia ferruginea and Erythrina brucei was higher in agroforestry than in culturally protected forest. Colonization of different AM structures of Croton macrostachyus, Millettia ferruginea, and Erythrina brucei was higher in agroforestry practices than those in culturally protected forest and lower for Prunus africana in agroforestry. 
The data also showed that AMF root colonization of plants in the cropland was always lower than those in agroforestry (Table 2). However, Duncan's multiple-range tests at $\mathrm{p}<0.05$ showed that mean $\mathrm{AC}$ in between $\mathrm{CPF}$ and $\mathrm{AF}$ were not significantly different (Table 2).

Table 2. Mean percentage colonization of the different fungal structures in the roots of the plants in different land use systems.

\begin{tabular}{|c|c|c|c|c|c|c|c|}
\hline \multirow{2}{*}{$\begin{array}{l}\text { CPF (Forest land Use \%) } \\
\text { Plants }\end{array}$} & \multirow[b]{2}{*}{$\mathrm{AC}$} & \multirow[b]{2}{*}{$\mathrm{VC}$} & \multicolumn{2}{|l|}{ AF (Agroforestry land use \%) } & \multirow[b]{2}{*}{$\mathrm{VC}$} & \multicolumn{2}{|c|}{$\begin{array}{l}\text { CL (Cropland } \\
\text { use } \% \text { ) }\end{array}$} \\
\hline & & & Plants & $\mathrm{AC}$ & & $\mathrm{AC}$ & $\mathrm{VC}$ \\
\hline Cordia africana Lam. & $17.48 \mathrm{a}$ & $29.40 \mathrm{~cd}$ & Cordia africana Lam. & $22.16 \mathrm{~cd}$ & $31.35 \mathrm{bc}$ & - & - \\
\hline Croton macrostachyus (HochstExDel.) & $19.30 \mathrm{a}$ & $24.04 b c$ & Croton macrostachyus (HochstExDel.) & $18.02 \mathrm{bc}$ & $28.02 b$ & - & - \\
\hline Millettia ferruginea Hochst & $21.81 \mathrm{a}$ & $32.90 \mathrm{~d}$ & Millettia ferruginea Hochst & $22.01 \mathrm{~cd}$ & $37.67 \mathrm{cde}$ & - & - \\
\hline Erythrina brucei Schweinf & $20.39 a$ & $28.20 \mathrm{bcd}$ & Erythrina brucei Schweinf & $21.44 \mathrm{~cd}$ & $31.42 \mathrm{bc}$ & - & - \\
\hline Prunus africana (Hook. f.) Kalkm. & $22.85 \mathrm{a}$ & $39.34 \mathrm{e}$ & Prunus africana (Hook. f.) Kalkm. & $14.73 b$ & $27.37 \mathrm{~b}$ & & \\
\hline Sub-mean & 19.55 & 27.41 & & 19.67 & 31.17 & - & - \\
\hline Hagenia abyssinica & $18.43 \mathrm{a}$ & $22.93 b$ & Catha edulis (vahl.) Forssk. exEndl & $29.53 \mathrm{e}$ & $38.22 \mathrm{cde}$ & $20.02 \mathrm{a}$ & $31.39 \mathrm{c}$ \\
\hline Juniperus procera $\mathrm{L}$. & $14.16 \mathrm{a}$ & $43.24 \mathrm{f}$ & Ensete ventricosum (Welw.) heesman) & $25.57 \mathrm{de}$ & $42.37 \mathrm{de}$ & $12.74 \mathrm{a}$ & $30.96 \mathrm{c}$ \\
\hline Podocarpus falcatus (Thunb.) R. Br. ex Mirb. & $23.33 \mathrm{a}$ & $25.35 \mathrm{bc}$ & Coffea arabica $\mathrm{L}$. & $23.98 \mathrm{~d}$ & $41.31 \mathrm{de}$ & $16.02 \mathrm{a}$ & $27.29 \mathrm{bc}$ \\
\hline Olea capensis L. & $18.77 \mathrm{a}$ & $22.48 b$ & Zea mays L. & $25.42 \mathrm{de}$ & $43.03 \mathrm{e}$ & $14.11 \mathrm{a}$ & $40.2 \mathrm{~d}$ \\
\hline Pouteria adolfi-friedericii (Engl.) & $20.68 \mathrm{a}$ & $14.46 \mathrm{a}$ & Phaseolus vulgaris $\mathrm{L}$. & $19.92 \mathrm{bcd}$ & $34.14 \mathrm{bcd}$ & $13.41 \mathrm{a}$ & $23.12 b$ \\
\hline Sub-mean & 19.89 & 29.06 & $\begin{array}{l}\text { Brassica integrifolia (West) O. E. Schulz } \\
\text { (Shana) }\end{array}$ & $0.77 \mathrm{a}$ & $1.55 \mathrm{a}$ & $0.01 \mathrm{a}$ & $0.01 \mathrm{a}$ \\
\hline \multirow[t]{4}{*}{ Grand mean } & 19.72 & 28.24 & Saccharum officinarum $\mathrm{L}$. & $20.03 \mathrm{bcd}$ & $32.02 \mathrm{bc}$ & $12.94 \mathrm{a}$ & $30.57 \mathrm{c}$ \\
\hline & & & Ipomoea batatas (L.) Lam. & $22.06 \mathrm{~cd}$ & $31.38 \mathrm{bc}$ & $20.14 \mathrm{a}$ & $29.71 \mathrm{c}$ \\
\hline & & & Sub-mean & 20.91 & 33.00 & 13.67 & 26.66 \\
\hline & & & Grand mean & 20.43 & 32.30 & 13.67 & 26.66 \\
\hline
\end{tabular}

$A C, V C$, percentage of hyphal, arbuscular and vesicular colonization respectively. Similar letters in columns show not significant difference between groups at $\mathrm{p}<0.05$

The total percentage mycorrhization (RLC) of the three land use types was in the range of $55.69 \%$ (Ensete ventricosum, in monocropping) to $90.52 \%$ (Coffea arabica, in agroforestry) (Table 3). In general, data showed that more mycorrhization occurred in agroforestry (mean mycorrhizal coverage of roots of $71.53 \%$ ) followed by forest land use systems (with mean mycorrhizal coverage of roots of $68.63 \%$ ) and the drastically changed mono-cropping system (mean mycorrhizal coverage of roots of 53.38\%). However, with a few exception, annual crops in mono cropping system showed higher mycorrhization $(>80 \%)$ than the woody and perennial plants in other land use systems.

With regard to spore density from the selected trees and crops of the three land use types the data shows that they harbored large number of spores ranging from 6 to 1009.7 spores $100 \mathrm{~g}^{-1}$ soil (Table 3). The pattern of spore count shows that relatively higher spore number was detected from forest land use (mean spore density of 752.9 spores $100 \mathrm{~g}^{-1}$ soil) followed by agroforestry system (mean spore density 638.7 spores $100 \mathrm{~g}^{-1}$ soil) and cropland (mean spore density 427.4 spores $100 \mathrm{~g}^{-1}$ soil) indicating that spore density decreases with extensive land use than the naturally managed agro-ecosystems.

With a few exceptions the data showed significant difference in spore abundance amongst trees in culturally protected forest (Table 3), however, the mean spore abundance was variable with the highest in Croton macrostachyus (1009.7) and the lowest in Juniperus procera (514.1). Spore abundance in agro-forestry practices and mono-cropping systems also showed statistically significant difference amongst almost all crops in mono-cropping systems (Table 3).

Table 3. Spore density and overall mycorrhization of the plants in the different land use systems.

\begin{tabular}{|c|c|c|c|c|c|c|c|}
\hline \multirow{2}{*}{$\begin{array}{l}\text { Forest land use } \\
\text { Plants }\end{array}$} & \multirow[b]{2}{*}{ SD/gm } & \multirow[b]{2}{*}{ RLC \% } & \multicolumn{2}{|l|}{ Agroforestry land use } & \multicolumn{3}{|c|}{ Crop land use } \\
\hline & & & Plants & SD/gm & RLC\% & SD/gm & RLC\% \\
\hline Cordia africana Lam. & $814.8 \mathrm{~d}$ & $77.93 d$ & Cordia africana Lam. & $803.3 \mathrm{e}$ & $76.23 \mathrm{de}$ & - & - \\
\hline $\begin{array}{l}\text { Croton macrostachyus } \\
\text { (HochstExDel.) }\end{array}$ & $1009.7 \mathrm{f}$ & $57.44 \mathrm{a}$ & Croton macrostachyus (HochstExDel.) & $983.78 \mathrm{~g}$ & $63.45 b c$ & - & - \\
\hline Millettia ferruginea Hochst & $747.9 \mathrm{~cd}$ & $80.52 d$ & Millettia ferruginea Hochst & $589.3 \mathrm{c}$ & $80.52 \mathrm{fg}$ & - & - \\
\hline Erythrina brucei Schweinf & $910.2 \mathrm{e}$ & $71.68 \mathrm{bcd}$ & Erythrina brucei Schweinf & $674 d$ & $78.77 \mathrm{def}$ & - & - \\
\hline Prunus africana (Hook. f.) Kalkm. & $665.4 b c$ & $58.85 \mathrm{ab}$ & Prunus africana (Hook. f.) Kalkm. & $581.78 \mathrm{c}$ & $58.85 b$ & - & - \\
\hline Hagenia abyssinica $L$. & $779.3 d$ & $62.70 \mathrm{~cd}$ & Catha edulis (vahl.) Forssk. exEndl & $968.78 \mathrm{~g}$ & $85.65 \mathrm{efg}$ & $664.89 \mathrm{e}$ & $67.08 \mathrm{~d}$ \\
\hline Juniperus procera $\mathrm{L}$. & $514.1 \mathrm{a}$ & $64.98 \mathrm{abc}$ & Ensete ventricosum (Welw.) Cheesman) & $633.1 \mathrm{~cd}$ & 84.71 efg & $542.4 d$ & $55.69 \mathrm{bc}$ \\
\hline $\begin{array}{l}\text { Podocarpus falcatus (Thunb.) R. } \\
\text { Br. exMirb. }\end{array}$ & $682.44 \mathrm{c}$ & $75.26 \mathrm{~d}$ & Coffea arabica $\mathrm{L}$. & $891.67 \mathrm{f}$ & $90.52 \mathrm{~g}$ & $654.56 \mathrm{e}$ & $57.39 \mathrm{c}$ \\
\hline Olea capensis $\mathrm{L}$. & $824.67 \mathrm{de}$ & $79.48 \mathrm{a}$ & Zea mays L. & $639.67 \mathrm{~cd}$ & $89.189 \mathrm{~g}$ & $442 \mathrm{c}$ & $65.98 \mathrm{~d}$ \\
\hline Pouteria adolfi-friedericii (Engl.) & $580.56 \mathrm{ab}$ & $57.85 \mathrm{a}$ & Phaseolus vulgaris L. & $449.2 b$ & $76.59 \mathrm{de}$ & $324.89 b$ & $49.94 b$ \\
\hline Sub-mean & 681.02 & 61 & Brassica integrifolia (West) O. E. Schulz (Shana) & $6.4 \mathrm{a}$ & $0.05 \mathrm{a}$ & $3.2 \mathrm{a}$ & $1.95 \mathrm{a}$ \\
\hline
\end{tabular}




\begin{tabular}{|c|c|c|c|c|c|c|c|}
\hline \multirow{2}{*}{$\begin{array}{l}\text { Forest land use } \\
\text { Plants }\end{array}$} & \multicolumn{3}{|r|}{ Agroforestry land use } & \multirow[b]{2}{*}{ SD/gm } & \multirow[b]{2}{*}{ RLC\% } & \multicolumn{2}{|c|}{ Crop land use } \\
\hline & SD/gm & RLC \% & Plants & & & SD/gm & RLC\% \\
\hline Mean & 752.91 & 68.63 & Saccharum officinarum L. & $444.3 b$ & $66.03 b c$ & $343.4 b$ & $58.63 \mathrm{c}$ \\
\hline & & & Ipomoea batatas (L.) Lam. & $608.89 \mathrm{~cd}$ & $71.87 \mathrm{~cd}$ & $444.1 \mathrm{c}$ & $70.38 \mathrm{~d}$ \\
\hline & & & Sub-mean & 580.25 & 68 & 427.4 & 53.38 \\
\hline & & & Mean & 638.74 & 71.53 & 427.4 & 53.38 \\
\hline
\end{tabular}

$\mathrm{SD}$, spore density; RLC, total root length colonization respectively. Similar letters in columns show not significant difference between groups at $\mathrm{p}<0.05$.

When the mean values for the three land uses from the three forest areas are compared, similar to AMF colonization, spore density also varied greatly between land-use types (Table 4). Mean spore density, 427.4 for cropped land, 638.74 for agroforestry and 752.91 per $100 \mathrm{~g}^{-}$ ${ }^{1}$ dry soil for culturally protected forest were significantly different. Also, there was difference in spore density of the same plant species in different land uses (Table 3). Cordia africana, Croton macrostachyus, Millettia ferruginea, Erythrina brucei, and Prunus africana (Hook. f) Kalkm that grow in both culturally protected forest and the agroforestry showed different mycorrhization levels and spore density.

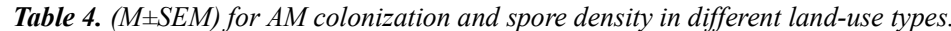

\begin{tabular}{lllll}
\hline Land use & AC\% & VC\% & RLC\% & Spore density (per 100 $\mathbf{g}^{-1}$ dry soil) \\
\hline Forest $(\mathrm{n}=30)$ & $19.7 \pm 1.3 \mathrm{a}$ & $28.2 \pm 0.6 \mathrm{a}$ & $68.6 \pm 0.7 \mathrm{a}$ & $752.9 \pm 14.2 \mathrm{a}$ \\
Agroforest $(\mathrm{n}=39)$ & $20.4 \pm 0.7 \mathrm{~b}$ & $32.3 \pm 1.0 \mathrm{a}$ & $70.2 \pm 0.9 \mathrm{~b}$ & $636.5 \pm 6.4 \mathrm{~b}$ \\
Cropland $(\mathrm{n}=24)$ & $13.7 \pm 0.4 \mathrm{~b}$ & $26.7 \pm 0.8 \mathrm{~b}$ & $53.4 \pm 1.0 \mathrm{~b}$ & $427.4 \pm 10.0 \mathrm{c}$ \\
\hline
\end{tabular}

Means followed by the different letters $(\mathrm{a}-\mathrm{c})$ in each column are significantly different within a given land-use type according to Duncan's multiple-range test at the $\mathrm{p}<0.05$ level of probability. $\mathrm{HC}, \mathrm{AC}, \mathrm{VC}$ and RLC are percentages of root length with hyphae, arbuscules, vesicles and total colonization respectively

\subsection{AMF Spore Community Composition}

A total of 29 AMF morphospecies, belonging to 9 genera (Acaulospora, Glomus, Claroideoglomus, Funneliformis, Gigaspora, Pacispora, Septoglomus, Rhizophugus and Scutellospora), were found in the rhizosphere of plants in the three land use systems. Spores of four genera Rhizophugus, Glomus, Funneliformis and Acaulospora showed higher spore production, accounting for $36.22 \%, 19.39 \%, 17.54 \%$ and $11.74 \%$ of the total number of spores respectively (Table 5). The results of this investigation also indicated that the species of AMF from genus Acaulospora, Glomus and Scutellospora were dominant. The genus Acaulospora contains the highest number of species (10) followed by Glomus (4) and Scutellospora (4) species.

Table 5. AMF spore community composition in the three land use systems.

\begin{tabular}{llll}
\hline Glomeromycotan genus & Morphotypes & Spore density & \%Composition (G/Tpd X 100) \\
\hline Rhizophugus & 2 & 762 & 36.22 \\
Glomus & 4 & 408 & 19.39 \\
Funneliformis & 2 & 369 & 17.54 \\
Acaulospora & 10 & 247 & 11.74 \\
Scutellospora & 4 & 106 & 5.04 \\
Claroidioglomus & 2 & 76 & 3.61 \\
Septoglomus & 1 & 61 & 2.90 \\
Gigaspora & 3 & 54 & 2.54 \\
Pacispora & 1 & 21 & 0.99 \\
\hline
\end{tabular}

Key: G, spore density of individual species; Tpd, total spore density of all species

Spores of Rhizophugus showed the highest number of spore production and spores of Claroideoglomus, Septoglomus, Pacispora and Gigaspora averaged less than $5 \%$ each. The four most frequently isolated species $R h$. intraradices $(70.9 \%)$, Rh. clarus $(64.71 \%)$, Glomus hoi (64.71\%) and Funneliformis mosseae (64.71\%) were more abundant in the three land uses (Table 6). Identification of spores was based on spore morphology and the number of morphospecies detected in the rhizosphere soil samples of the most common trees and crops in the three land use systems ranged from 21 to 29 . In the agroforestry systems were detected 25 morphospecies. The forest had the highest number of morphospecies (26), and the least morphotypes were found in mono-cropping systems (21). The Shannon diversity index showed ranges in between 2.077 in croplands to 2.494 in culturally protected forest and evenness was ranged from 0.2851 (the smallest) in cropland to 0.4175 (the highest in culturally protected forest. Simpson's Index of Diversity (1-D) shows the highest value for culturally protected forest (0.8565), agroforestry $(0.8273)$ and the lowest $(0.7288)$ for the crop land (data not shown).

Individual plant species compared also showed variation in having the different morphospecies (Table 6). Accordingly more than 19 morphospecies were detected from Millettia ferruginea followed by Croton macrostachyus (16 
morphospecies). From Cordia africana and Prunus africana were detected 15 morphospecies. From Erythrina brucei, Catha edulis and Coffea arabica were detected 14 morphospecies respectively. The lowest number of morphospecies was recorded for Hagenia abyssinica (8) and Pouteria adolfi-friedericii (8) (Table 6).

Table 6. Isolation Frequency (IF), Relative abundance (RD) and Importance Value (IV) of AMF in rhizosphere soils of culturally protected forest, agroforestry and cropland.

\begin{tabular}{|c|c|c|c|c|c|c|c|c|c|c|c|c|c|c|c|c|c|c|c|c|}
\hline AMF Genus/species Identified & 1 & 2 & 3 & 4 & 5 & 6 & 7 & 8 & 9 & 10 & 11 & 12 & 13 & 14 & 15 & 16 & 17 & $\%$ IF & $\%$ RD & IV\% \\
\hline $\begin{array}{l}\text { Acaulospora cavarnata } \\
\text { (Blaszk.(1989)) }\end{array}$ & + & - & + & + & - & - & + & - & - & + & - & - & - & - & + & - & - & 35.29 & 1.22 & $18 \mathrm{c}$ \\
\hline $\begin{array}{l}\text { Acaulopsora foveata (Trappe } \\
\text { \&Jonos (1982)) }\end{array}$ & + & - & + & - & + & - & - & - & + & - & - & + & - & + & - & + & - & 41.18 & 0.58 & $21 \mathrm{c}$ \\
\hline $\begin{array}{l}\text { Acaulospora tuberculata (Trappe } \\
\text { \&Jonos (1982)) }\end{array}$ & + & - & + & - & + & - & - & - & + & + & - & + & - & + & - & - & - & 41.18 & 4.48 & $23 c$ \\
\hline $\begin{array}{l}\text { Acaulospora spinosa }(\mathrm{C} . \\
\text { Walker\& Trappe (1981)) }\end{array}$ & + & - & + & + & + & - & - & + & - & - & + & - & + & - & - & - & - & 41.18 & 0.77 & $21 \mathrm{c}$ \\
\hline $\begin{array}{l}\text { Acaulospora denticulate (Sieved. } \\
\& \text { S. Toro (1987)) }\end{array}$ & - & + & - & - & - & + & + & - & - & - & + & - & + & - & - & - & + & 35.29 & 0.86 & $18 \mathrm{c}$ \\
\hline $\begin{array}{l}\text { Acaulospora koskei (Blazsk. } \\
(1995))\end{array}$ & - & + & - & + & + & - & - & - & - & + & - & - & - & + & - & + & - & 35.29 & 0.72 & $18 \mathrm{c}$ \\
\hline $\begin{array}{l}\text { Acaulospora colombiana (Spain } \\
\text { \& N. C. Schenck) Kaonongbua, } \\
\text { J. B. Morton \&Bever (2010) }\end{array}$ & - & - & + & - & - & - & + & - & - & - & + & - & - & - & - & - & - & 17.65 & 0.32 & $9 \mathrm{r}$ \\
\hline Acaulospora sp.1. & + & + & - & + & + & - & - & - & + & - & + & - & - & + & - & - & + & 47.06 & 0.9 & $23 \mathrm{c}$ \\
\hline Acaulospora sp.3 & - & + & + & - & - & - & + & - & - & - & + & - & + & - & - & + & - & 35.29 & 0.41 & $18 \mathrm{c}$ \\
\hline $\begin{array}{l}\text { Claroideoglomus etunicatum (W. } \\
\text { N. Becker\&Gerd. C. } \\
\text { Walker\&Schuessler (2010)) }\end{array}$ & - & + & - & + & - & + & - & - & + & - & - & + & - & - & + & - & + & 41.18 & 1.44 & $21 \mathrm{c}$ \\
\hline $\begin{array}{l}\text { Claroideoglomus claroideum (N. } \\
\text { C. Schenck\&G. S. Sm. C. } \\
\text { Walker\&Schuesseler (2010)) } \\
\text { Funneliformis mosseae (T. H. }\end{array}$ & + & + & + & + & + & - & - & + & - & - & + & - & + & - & + & - & + & 58.82 & 1.99 & $30 \mathrm{c}$ \\
\hline $\begin{array}{l}\text { Nicolson\&Gerd.) C. } \\
\text { Walker\&Schuessler (2010) }\end{array}$ & + & + & + & + & + & + & - & - & - & - & + & + & + & + & - & + & - & 64.71 & 12.52 & $39 \mathrm{c}$ \\
\hline $\begin{array}{l}\text { Funneliformis geosporum (T. H. } \\
\text { Nicolson\&Gerd.) C. } \\
\text { Walker\&Schuessler (2010) }\end{array}$ & - & + & - & - & - & + & - & + & - & - & + & - & + & - & - & - & - & 29.41 & 4.16 & $17 \mathrm{c}$ \\
\hline $\begin{array}{l}\text { Rhizophagu intraradices (N. C. } \\
\text { Schenck\&G. S. Sm. C. } \\
\text { Walker\&Schuesseler (2010)) }\end{array}$ & + & + & + & + & + & - & + & - & - & - & + & + & + & + & - & + & + & 70.59 & 15.82 & $44 c$ \\
\hline $\begin{array}{l}\text { Glomus hoi (S. M. Berch\& } \\
\text { Trappe (1985)) }\end{array}$ & + & + & + & + & + & & + & & + & - & + & - & + & - & + & + & - & 64.71 & 16.23 & $41 \mathrm{c}$ \\
\hline $\begin{array}{l}\text { Glomus aggregatum (N. C. } \\
\text { Schenck\&G. S. Sm. (1982)) }\end{array}$ & - & + & + & + & - & - & - & + & - & - & + & - & - & - & + & - & - & 35.29 & 0.68 & $18 \mathrm{c}$ \\
\hline Gloти sp.1 & - & - & + & - & - & - & + & - & - & + & - & - & - & - & - & - & + & 23.53 & 0.36 & $12 \mathrm{c}$ \\
\hline Gloms sp.2 & - & + & - & - & + & - & - & + & - & + & - & - & + & - & - & + & - & 35.29 & 1.18 & $18 \mathrm{c}$ \\
\hline $\begin{array}{l}\text { Gigaspora rosea (T. H. Nicolson } \\
\text { \&N. C. Schenck (1989)) }\end{array}$ & + & - & + & + & + & - & - & - & - & + & - & - & + & - & + & - & - & 41.18 & 5.2 & $23 \mathrm{c}$ \\
\hline Gigaspra sp. 1 & - & + & - & - & - & + & - & + & - & - & - & - & + & - & + & - & + & 35.29 & 1.54 & $19 \mathrm{c}$ \\
\hline $\begin{array}{l}\text { Gigaspora sp. } 2 \\
\text { Pacispora scintillans (S. L. Rose }\end{array}$ & - & - & + & + & - & - & + & - & + & - & - & + & - & - & + & - & - & 35.29 & 0.59 & $18 \mathrm{c}$ \\
\hline $\begin{array}{l}\text { \& Trappe) C. Walker, Vestberg \& } \\
\text { Schuessler (2007) } \\
\text { Septoglomus constructum }\end{array}$ & - & - & + & - & + & - & - & - & + & - & + & + & - & + & - & + & - & 41.18 & 0.95 & $21 \mathrm{c}$ \\
\hline $\begin{array}{l}\text { (Trappe) C. Walker \& Schuessler } \\
(2010)\end{array}$ & + & - & + & - & - & + & - & + & - & - & + & + & + & + & - & + & - & 52.94 & 2.76 & $28 \mathrm{c}$ \\
\hline Scutellospora sp. 1 & + & + & & + & + & + & - & - & + & - & - & + & - & + & - & + & - & 52.94 & 2.76 & $28 \mathrm{c}$ \\
\hline Scutellospora sp. 2 & - & + & + & - & - & - & + & - & + & - & - & + & - & + & - & + & - & 41.18 & 1.31 & $21 \mathrm{c}$ \\
\hline Scutelospora sp.3 & + & - & - & - & - & + & - & + & - & - & + & - & - & - & + & - & - & 29.41 & 0.36 & $15 \mathrm{c}$ \\
\hline Scutelospora sp. 4 & - & - & - & + & - & - & - & + & - & + & - & - & + & - & + & - & + & 35.29 & 0.36 & $18 \mathrm{c}$ \\
\hline
\end{tabular}

Key: 1, Cordia africana; 2, Croton macrostachyus; 3, Millettia ferruginea; 4, Erythrina brucei; 5, Prunus africana.; 6, Hagenia abyssinica.; 7, Podocarpus falcatus; 8, Juniperus procera; 9, Olea capensis; 10, Pouteria adolfi-friedericii; 11, Catha edulis; 12, Ensete ventricosum; 13, Coffea arabica; 14, Zea mays; 15, phaseolus vulgaris; 16, Saccharum officinarum; 17, Ipomoea batata; c, common; r, rare; + Present; - Absent 

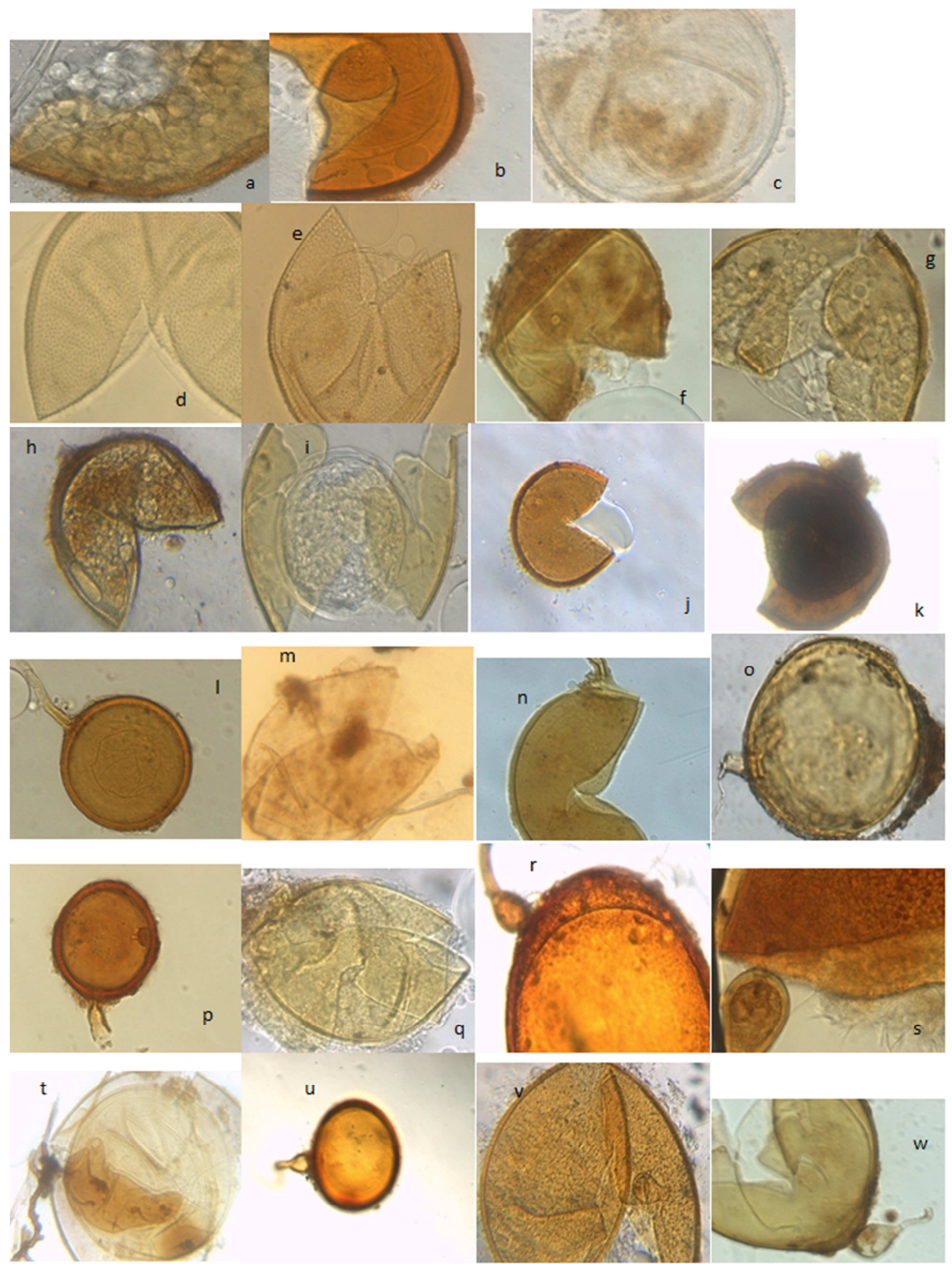

Figure 1. Some of the Glomeromycotan species identified from rhizosphere soil samples of CPF, AF \& CL. a) Ac. denticulate b) Ac. koskei c) Pacispora scintillans d) Ac. cavarnata e) Ac. faveatac f) Ac. tuberculata g) Acaulospora sp.1 h) Ac. spinosa i) Acaulospora sp. 2 j) Acaulospora sp. 3 k) Ac. colombiana, l) Glomus hoi m) Rh. intraradices n) Cla. claroideum o) Fu. mosseae p) Sept. constructum q) Rh. clarus r) Scutellospora sp.1 s) Scutellospora sp.2 t) Scutellospora sp. 3 u) Scutellospora sp.4 v) Gig. rosea w) Gigaspora sp.1. All spores were mounted in PVLG. 


\section{Discussion}

In this study different plants species from different land use types (agroforestry and crop lands) in reference to the culturally protected forests were sampled and studied for mycorrhizal diversity, root colonization and spore density. Based on spore morphology a total of 29 AMF species belonging to nine genera; Acaulospora, Glomus, Claroideoglomus, Funneliformis, Gigaspora, Pacispora, Septoglomus, Rhizophugus and Scutellospora were detected. The twenty nine species isolated from different land uses in Sidama is higher compared to 15-18 AM species recorded in the acid soils of Western Kenya and agroforestry systems in the miomboecozone of Malawi [16], 17 AMF species from tropical humid high land of Kenya [13] and 17 AMF species from soil fertility management systems in Nigeria [11] and lower compared to other similar studies; 40 AM species recorded in Cameroon rain forest [15], 42 from Acacia trees in different land uses in Ethiopia [32], 44 from semiarid grasslands of Namibia [29] and 60 from sub-Saharan Savannas of Benin, West Africa [26]. Likewise, 43 AM species were isolated from Western Brazilian Amazon [25].

Spores of four genera; Rhizophugus, Glomus, Funneliformis, Acaulospora and Claroidioglomus had higher spore production, accounting for $36.22 \%, 19.39 \%, 17.54 \%$ and $11.74 \%$ of the total number of spores respectively. These results were comparable to the diversity of AMF described in Senegal [6,7], in Ethiopia [32] and other countries. The Genus Rhizophugus and Glomus were the most abundant in these investigated land uses.

Based on the one-way analysis of variance (ANOVA), the colonization of different AM structures varied greatly among plant species both within and between land-use types. This result is supported by other findings [14]. Vesicular colonization was the largest in between $26.66-33 \%$. The largest rate of vesicular colonization is may be because vesicles develop to accumulate storage products in many $\mathrm{AMF}$ associations and remain in roots for months or years [4], while the arbuscules are short-lived. Mean AMFcolonization levels in agroforestry practices were moderately higher $(68 \%)$ compared to cropland (53.38\%), result supported by previous findings [32] in different parts of Ethiopia. For current experimental sites, spore abundance was highest (681) in land use with lower intensity (the culturally protected forest) and less abundant (580 \& 427) in other land uses: agroforestry and cropland respectively. Soils from agroforestry had both high spore abundance (next to $\mathrm{CPF}$ ) and high root colonization $(73 \%)$. These is because with the exception of cropland, the rest of the land uses were dominated by perennial plants which had the highest root colonization that might be attributed to continuous root growth throughout and less disturbance through cultivation. Coffea arabica, Ensete ventricosum, Catha edulis and other perennial crops and trees in agroforestry are often intercropped with food crops and receive one to two times a year slashing and manual weeding. This form of interference may explain the high root colonization and lower disruption of mycelia manifested in slightly higher AMF colonization in agroforestry as compared to culturally protected forests. In the present study the observed lower spore density and percentage root colonization in croplands may be attributed to continuous tillage and crop shifting throughout the year in these small holder farms that disrupt hyphal growth and sporulation [8]. Therefore, the difference in mean spore density of AMF from 427.4 in cropland to 752.91 spores (100 $\mathrm{g}^{-1}$ dry soil) in culturally protected forest indicates that root colonization and spore density are dependent on the practices of soil management in the study area.

In the present study spore density also differed significantly among plant species both within and between land use types indicating uneven distribution of AMF spores. According to [19], AM fungal sporulation is influenced by an array of factors which come from environment, host and fungus and spore density tend to decrease during early root growth but to increase during root inactivity or senescence. [31] suggested that the uneven spatial distribution of AM fungal spores and the complex structure of the underground root component should be considered as major factors affecting spore density of AMF. Mean separation showed that the spore density in culturally protected forest was significantly higher than those in agroforest and cropland, which further supported the view that disturbance reduced spore density [12]. Five of the multipurpose trees (some of them leguminous) occurring in the culturally protected forest and the agroforest; Cordia africana, Croton macrostachyus, Millettia ferruginea, Erythrina brucei and Prunus africana, have a relatively high spore density. No significant correlation between AMF colonization and spore density was observed when land-use types were either considered separately or together, which is consistent with several previous reports [27, 32].

Though, AMF status of most plant species investigated were already reported before, to the best of our knowledge mycorrhizal status of the following plant species in Ethiopia have never been reported before to form AM: Erythrina brucei, Hagenia abyssinica, Juniperus procera, Podocarpus falcatus, Catha edulis and Ensete ventricosum. Therefore, these plant species growing in culturally protected forest, agroforestry and mono-cropping systems in Sidama can be added to the list of AM plants.

The increase in spore density and diversity with an increase in soil available $\mathrm{P}$ observed in culturally protected forest was may be because the concentration of $\mathrm{P}$ is not high enough to influence mycorrhizal development [18]. As far as soil texture is concerned, soil samples were sandy clay loam in Bokasso forest area and Sandy loam in Tellamo and Arrosa forest areas and according to findings of [5], these are types of soils that favor mycorrhizal development. Soil $\mathrm{pH}$ was in between 6.18 to 6.28 , conducive for AMF development.

It has been well shown that among the biotic factors that could favor rapid plant re-establishment, promote plant growth, and alleviate abiotic stress, AM symbiosis is the most effective [9]. This study provides basic information on 
the AMF status and indicates differences in AMF colonization and spore density of culturally protected forest, agroforestry practices and cropland at Wensho and Shebedino districts of Sidama (Ethiopia) where agroforestry practices are dominating. This knowledge, therefore, is necessary for the reclamation and restoration of this ecosystem. Also, the results indicated that AMF colonization and spore density was reduced by continuous cropping and soil disturbance in croplands. Therefore, multipurpose agroforestry systems are effective for sustained environmental productivity, soil structure maintenance and for the restoration of AM status as compared with cropped land and culturally protected forest ecosystem in this study area.

\section{Conclusion}

This study provides basic information on the AMF status, AMF colonization and spore density in culturally protected forest, agroforestry practices and cropland in Wensho and Shebedino districts of Sidama (Ethiopia). The current study showed that AMF are important components in the three land use types. The results also indicated that AMF colonization and spore density were reduced by continuous cropping and soil disturbance in croplands. Culturally protected forests exhibited high spore density whereas the agroforestry system showed high root colonization. Culturally protected forest also harbored more species diversity as compared to the other two land uses. The small holder agroforestry practices with mixed trees (some leguminous) and perennial crops also displayed more root colonization and relatively higher spore density next to culturally protected forest.

The study, in general, showed that agroforestry systems are effective for sustained environmental productivity, soil structure maintenance and for the restoration of AM status as compared to cropped land and culturally protected forest ecosystem. Therefore, diversification of crops may enhance soil biological and chemical properties and in return improve crop production.

\section{Acknowledgments}

We would like to acknowledge Hawassa College of Teacher Education for financial and logistic supports, Department of Microbial, Cellular and Molecular Biology, Addis Ababa University, Wendo Genet College of forestry and College of Agriculture, Hawassa University for providing laboratory equipment and chemicals. Finally we would like to thank Mauritz Vestberg $(\mathrm{PhD})$ and Zerihun Belay $(\mathrm{PhD})$ for their unreserved comments on taxonomic positions of AMF spores.

\section{References}

[1] Allen, M. F., Helm, D. T., Trappe, J. M., Molina, R. and Rincón, E. (1995). Patterns and regulations of mycorrhizal plant and fungal diversity. Plant Soils, 170: 47-62.

[2] Amerian, M. R. and Stewart, W. S. (2001). Effect of 2 species of arbuscular mycorrhizal fungi on growth assimilation and leaf water relations in maize (Zea mays). Aspects of Applied Biology, 63: 1-6.

[3] Azcón-Aguilar, C. and Barea, J. M. (1996). Arbuscular mycorrhizas and biological control of soil-borne plant pathogens-an overview of the mechanisms involved. Mycorrhiza, 6: 457-464.

[4] Brundrett, M., Melville, L. and Peterson, L. (1994). Practical Methods in Mycorrhiza Research. Mycologue Publications, University of Guelph, Guelph, Ontario, Canada.

[5] Carrenho, R., Trufem, S. F. B., Bononi, V. L. R. and Silva, E. S. (2007). The effect of different soil properties on arbuscular mycorrhizal colonization of peanuts, sorghum and maize. Acta. Bot. Bras., 21: 23-730.

[6] Catford, J., Staehelin, C., Lerat, S., Piché, Y. and Vierheilig, H. (2000). Suppression of arbuscular mycorrhizal colonization and nodulation in split-root systems of alfalfa after preinoculation and treatment with Nod factors. Journal of Experimental Botany, 54: 481-1487.

[7] Chen, K., Liu, W., Guo, S., Liu, R. and Li, M. (2012). Diversity of arbuscular mycorrhizal fungi in continuous cropping soils used for pepper production. African Journal of Microbiology Research, 6: 469-2474.

[8] Douds, D. D. and Millner, P. (1999). Biodiversity of arbuscular mycorrhizal fungi in agroecosystems. Agriculture, Ecosystem and Environment, 74: 7-93.

[9] Duponnois, R., Plenchette, C., Thioulouse, J. and Cadet, P. (2001). The mycorrhizal soil infectivity and arbuscular mycorrhizal fungal spore communities in soils of different and aged fallows in Senegal. Applied Soil Ecology, 17, 239-251.

[10] EFAP. 1993. Ethiopian forestry action program: the challenge for development (Vol. I). Ministry of Natural Resources Development and Environmental Protection, Addis Ababa, Ethiopia.

[11] Emmanuel, B., Fagbola, O., Abaidoo, R., Osonubi, O. and Oyetunji, O. (2010). Abundance and distribution of arbuscular mycorrhizal fungi species in long-term soil fertility management systems in Northern Nigeria. Journal of Plant Nutrition, 33: 264-1275.

[12] Enkhtuya, B., Rydlová, J. and Vosátka, M. (2000). Effectiveness of indigenous and non-indigenous isolates of arbuscular mycorrhizal fungi in soils from degraded ecosystems and manmade habitats. Applied Soil Ecology, 14, 201-211.

[13] Jefwa, J. M., Mung'atu, J., Okoth, P., Muya, E., Roimen, H. and Njuguini, S. (2009). Influence of land use types on occurrence of arbuscular mycorrhizal fungi in the high altitude regions of Mt. Kenya. Tropical and Subtropical Agroecosystems, 11: 77- 290

[14] Li, L. F., Li T. and Zhao, Z. W. (2007). Differences of arbuscular mycorrhizal fungal diversity and community between a cultivated land, an old field, and a never-cultivated field in a hot and arid ecosystem of southwest China. Mycorrhiza 17: 55-665.

[15] Mason, P. A., Musoko, M. O. and Last, F. T. (1992). Short-term changes in vesicular-arbuscular mycorrhizal spore populations in Terminalia plantations in Cameroon. In: Read, D. J., Lews, D. H., Fitter, AH., Alexander, I. J (eds.). Mycorrhizas in ecosystems. Wallingford: CAB International. Pp. 261-267. 
[16] Mathimaran, N., Ruh, R., Jama, B., Verchont, L. and Frossard. (2007). Impact of agricultural management on arbuscular mycorhizal fungal communities in Kenyan ferrasol. Agriculture Ecosystems and Environment, 119: 2-32.

[17] McGonigle, T. P., Evans, D. G. and Miller, R. M. (1990). Effect of degree of soil disturbance on mycorrhizal colonization and phosphorus absorption by maize in growth chamber and field experiments. New Phytologist, 116: 629-636.

[18] Muleta, D., Assefa, F., Nemomissa, S. and Granhall, U. (2007). Composition of coffee shade tree species and density of indigenous arbuscular mycorrhizal fungi (AMF) spores in Bonga natural coffee forest, southwestern Ethiopia. Forest Ecology and Management, 241: 45-154.

[19] Muthukumar, T., Sha, L. Q., Yang, X. D., Cao, M., Tang, J. W. and Zheng, Z. (2003b). Mycorrhiza of plants in different vegetation types in tropical ecosystems of Xishuangbanna, southwest China. Mycorrhiza, 13, 289-297.

[20] Phillips, J. M. and Hayman, D. S. (1970). Improved procedure for clearing roots and staining parasitic and vesicular arbuscular mycorrhizal fungi for rapid assessment of infection. Trans Br Mycol Soc., 55: 58-161

[21] Richter, B. S., Tiller, R. L. and Stutz, J. C. (2002). Assessment of arbuscular mycorrhizal fungal propagules and colonization from abandoned agricultural fields and semi-arid grasslands in riparian flood-plains. Applied Soil Ecology, 20: 227-238.

[22] Schenck, N. C. and Pérez, Y. (1990). Manual for the Identification of VA Mycorrhizal Fungi. SynergisticPublications, Gainesville, Florida.

[23] Smith, S. E. and Read, J. D. (2008). Mycorrhizal symbiosis, 2nd ed. Academic Press Ltd., London, England.

[24] Steinberg, P. D. and Rillig, M. C. (2003). Differential decomposition of arbuscular mycorrhiza fungal hyphae and glomalin. Soil Biology and Biochemistry, 35: 191-194.
[25] Stürmer, S. L. Siqueira, J. O. (2011). Species richness and spore abundance of arbuscular mycorrhizal fungi across distinct land uses in Western Brazilian Amazon. Mycorrhiza, 21: 55-267.

[26] Tchabi, A, Coyne, D., Hountondji, F., Lawouin, L., Wiemken, A. and Oehl, F. (2008). Arbuscular mycorrhizal fungal communities in sub-Saharan Savannas of Benin, West Africa, as affected by agricultural land use intensity and ecological zone. Mycorrhiza, 18: 81-195.

[27] Tilal, S. A., Maria, R. F., Abdel, G. B. and Fritz, O. (2013). Species composition and diversity of arbuscular mycorrhizal fungi in White Nile state, Central Sudan, Archives of Agronomy and Soil Science.

[28] Trappe, J. (1987). Phylogenetic and ecologic aspects of mycotrophy in the angiosperms from an evolutionary standpoint In: Safir GR, ed. Ecophysiology of VA mycorrhizal plants. Boca Raton, Florida, USA: CRC Press, pp. 5-25.

[29] Uhlmann, E., Görke, C., Petersen, A. and Oberwinkler, F. (2004). Arbuscular mycorrhizae from semiarid regions of Namibia. Canadian Journal of Botany 82: 45-653.

[30] Van der Heijden, M. G., Klironomos, J. N., Ursic, M., Moutoglis, P., Streitwolf-Enge, 1 R., Boller, T., Wiemken, A. and Sanders, I. R. (1999). Sampling effect', a problem in biodiversity manipulation? A reply to David A. Wardle. Oikos. 87: 408-410.

[31] Zhao, Z., Xia, Y., Qin, X., Li, X., Cheng, L., Sha, T. and Wang G. (2001). Arbuscular Mycorrhizal status of plants and the spore density of arbuscular Mycorrhizal fungi in the tropical rain forest of Xishuangbanna, southwest China. Mycorrhiza, 11: $159-162$.

[32] Zerihun Belay, Vestberg, Z. M, Fassil Assefa. (2014). Diversity and abundance of arbuscular mycorrhizal fungi associated with acacia trees from different land use systems in Ethiopia. Africa Journal of Microbiology Research, 7 (48): 503-5515. 